\title{
実験的腎障害犬における副甲状腺機能について
}

\author{
東京大学医学部中尾内科（指導 中尾喜久教授） \\ 折茂肇

\section{PARATHYROID FUNCTION IN DOGS WITH EXPERIMENTAL RENAL LESIONS} \\ Hajime ORIMo \\ The Third Department of Internal Medicine, \\ Faculty of Medicine, University of Tokyo \\ (Director: Prof. Kiku Nakao M.D)
}

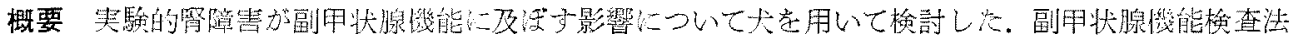

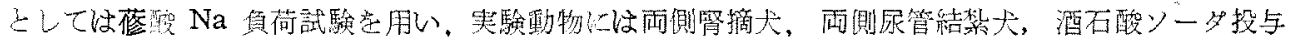

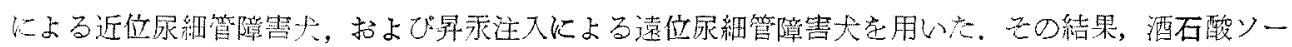

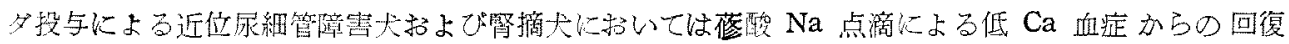

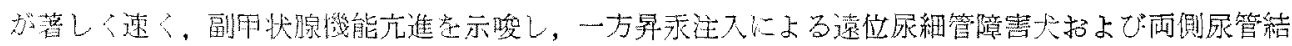

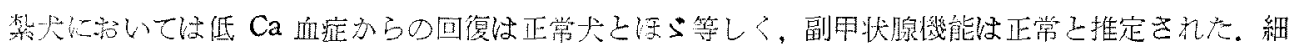

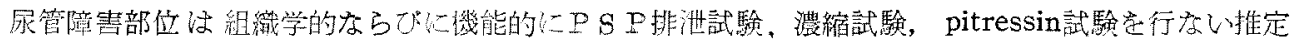

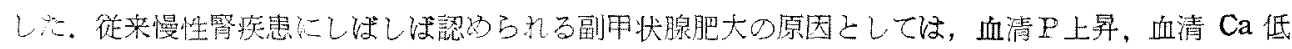

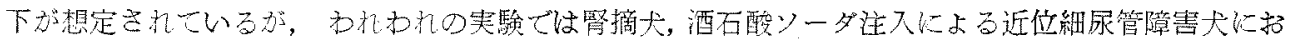
いては血清Caは己もに正常であり，從来の説のみでは説明困難己考元ら机る。
\end{abstract}

\section{I. 緒 言}

腎と副甲状腚との関係は古くから注目されてお り，1905年McCallumが慢性掔灸において副甲 状腺の肥大乙細胞分裂像の增加を認めて以来，数 多くの研究者により，慢性腎疾患の祭にしばしば 副甲状腺機能艺進を来たすことが確認されるに至 つた、しかるにその機序にかんしては，征来より 高P血症乃至 浜C $\mathrm{C}$ 血定による副甲状㩆刺激説 が有力ではあるが，詳細は未だに不明といわざる を得ない現状である。一力, 最近ではRasmussen ら2)により得られた精製副甲状腺ホルモンを用 い，副甲状腺ホルモンの繁尿細管に刘する作用が 詳細に検討され，とくに症細管レバルでの燐再吸

本論文の要旨は籍11回内分泌学会東部会総会におい て発表した。
収，乃至は分泌を放ぐつて活発に議論が茭されて いる.すなわち副甲状腺ホルモンの尿中燃排泄の 機序をめぐつて，近拉尿細管燐再吸收抑制説已遠 位尿細管烧分泌説とが対立して抢り，また臨床的 には原発性副甲状腺機能九進症の際の尿濃縮力障 害が問題となつている。以上の如く副甲状腚ホル モンの腎に対する作用は詳細に検討されている が，逆に鳌障害，とくに尿細管障害の際の副甲状 腺機能にかんしては極めて知見に无しく，わずか 汇臨床的に腎性クル病として総括され特異な尿細 管機能異常者伴索うPhosphate diabetes, Fanconi syndrome, renal tubular acidosisなどにお いて副甲状腺機能が問題上されているに過ぎな

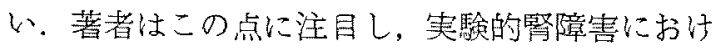
る副甲状腺機能㧍よびその機序について若干の検 討を行なつた。 


\section{II. 実験方法および動物}

体重 7.7 12.7 kgの雌雄大を一夜絶食後, つぎ の6群に分け実験に用いた。糜醉はチオベンター ルNa考用い，充分深く麻酸させた。

第 1 群 正常大 6 頭

第 2 群 甲状腺副甲状腺摘出犬 3 頭

大の副甲状腺は甲状腺組織の内部に包埋される もの 1 個と，甲状腺から遊離して上極または下極 に1個，而側で訫 4 個見出されるが，これらを確 認した後，甲状腺副甲状腺を摘出した，摘出は実 験前24時間乃至72時間前に行なつた。

第 3 群 $\mathrm{a}$ ）両側緊摘大 6 頭

b ）甲状腺副甲状腺摘出後雨側腎摘犬 3 頭

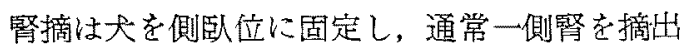
後，直ちに反対側に固定，対側韰を摘出した，摘 出は実験直前乃至48時間前に行なつた。

第 4 群 両側尿管結禁犬 4 頭

尿管結禁は犬を背卧位に固定後，膀胱上部にて 腹部に正中切開を加え，両側尿管が膀胱に入る直 前において結禁した。結禁は㬰験前24時間前に行 なつた。

第 5 群 a ）酒石酸ソーダ投与による近位尿細 管障害犬 5 頭

$30 \%$ 酒石酸ソーダ $5 \mathrm{ml} / \mathrm{kg}$ 老数力所に皮下注射 後, 24〜48時間絶食, 脱水後実験に用いた。

b ）甲状腹副甲状腺摘出後，酒石酸 ソーダ投与大 3 頭

第 6 群 昇永注入による遠位廌細管障害犬 3 頭

$0.05 \% \mathrm{HgCl}_{2}$ 液を $150 \mathrm{~cm}$ の高さに固定した点 滴装置上り両側尿管を経て逆行性に珡に5 分間注 入, 生理食塩水にて洗涤後 48 万至72時間徯に奏験 に用いだ）、以上第 $4,5,6$ 群に㧠いては実験終了 後扔のおの腎を摘出しフォルマリン固定パラフィ ン包埋後アザン染色にて組織学的に障害部位の検 索を行なつた。

副甲状腺機能検查法

副甲状腺機能娭査法としては苳酸 $\mathrm{Na}$ 負荷試
験45)を用いた。すなわ葆酸 $\mathrm{Na}$ 点滴前に採血後， 直ちに生理食塩水に溶解した葆酸 Na $400 \mathrm{mg} / 100$ $\mathrm{ml}$ 溶液を $40 \mathrm{mg} / \mathrm{kg}$ の割合に15２0分間に点滴静注 する，点滴直後方上び点滴直後上り15分，30分， 以後30分毎に 3 時間にわたつて採血する，採血は 全て股静脈より行なつた。血残Ca定量はMunson-Iseri変法（EDTA滴定法6) に上り行なつ た。Ca $10 \mathrm{mg} / 100 \mathrm{ml}$ 含む標準液10本の平均標準 諆差は土0.05mgであつた。血清 $\mathrm{P}$ 定量はFiske \& Subbarow法により行なつた，血獎Caレベルの回 復を一つの曲楾として表わ寸春験式を求めるため に，跱間（T）に10を加えた值上対応する各Ca 值の常用刘数值求め， それてれ秋， $\mathrm{y}_{\mathrm{i}}$ とする $\left(x_{i}=\log _{10}(10+\mathrm{T}), \mathrm{y}_{\mathrm{i}}=\log _{10}(\mathrm{Ca}), \mathrm{i}=0.1 \cdots \cdots\right.$ $\mathrm{N}, \mathrm{i}=0$ 值は苳酸 $N a$ 点滴直徯示す). $\mathrm{x}_{\mathrm{i}}, \mathrm{y}_{\mathrm{i}}$ の 平方和 (Sxx, Syy) および共变勤 ( $\mathrm{Sxy}$ ) 計算 する。

$$
\begin{aligned}
& \text { Sxx }=\sum_{0}^{N} x_{i}{ }^{2}-\frac{\left(\sum_{0}^{N} x_{i}\right)^{2}}{N} \\
& \text { Syy }=\sum_{0}^{N} y_{i}{ }^{2}-\frac{\left(\sum_{0}^{N} y_{i}\right)^{2}}{N} \\
& \text { Sxy }=\sum_{0}^{N} x_{i} y_{i}-\frac{\sum_{0}^{N} x i \sum_{0}^{N} y_{i}}{N}
\end{aligned}
$$

以上加ら淔線回帰の平方和 $(\mathrm{SR})$ 々直線回帰前 らのへだたりの平方和（SDR）を次表の如く計算 し, $\mathrm{SR}$ と直線回帰からのへたたりの不倔分散 $\mathrm{VDR}$ の商 $\mathrm{F}_{0}=\frac{\mathrm{SR}}{\mathrm{VDR}}$ が自由度 $\mathrm{n}_{1}=1, \mathrm{n}_{2}=\mathrm{N}-2$ の $\mathrm{F}(0.05)$ 上り大きい場合, $\mathrm{x}$ 一のyの回帰曲線の 一次部分が有意であり，同時にx.y の相関你数 $\frac{\text { Sxy }}{\sqrt{\text { Sxx Syy }}}-$ が有意であることを示すことにな る. $\mathrm{F}_{0}<\mathrm{F}_{\mathrm{N}}-2(0.05)$ の場合は血浆Caの対数値 の変動が時間（T）に10を加えた值の対数值の変 化に無関拯であることを示す，直線が有意である ことが示された堭合には，最小自涞法によりメ のyの回帰曲線 $y=a+b x$ 計算する。

$$
b=\frac{N \sum_{0}^{N} x_{i} y_{i}-\sum_{0}^{N} x_{i} \sum_{0}^{N} y_{i}}{N \sum_{0}^{N} x_{i}{ }^{2}-\left(\sum_{0}^{N} x_{i}\right)^{2}}
$$




$$
a=\frac{\sum_{0}^{N} y_{i} \sum_{0}^{N} x_{i}{ }^{2}-\sum_{0}^{N} x_{i} \sum_{0}^{N} x_{i} y_{i}}{N \sum_{0}^{N} x_{i}^{2}-\left(\sum_{0}^{N} x_{i}\right)^{2}}
$$

この箺駼式加ら期待回復時間“ expected time of recovery” ( $\mathrm{ETR}$ ) (苳酸 $\mathrm{Na}$ 点滴前の血漿 Caレベルに回復するまでの時聞）

$$
\begin{gathered}
\text { ETR }=\operatorname{anti} \log \left(\frac{y_{p}-a}{b}\right)-10 \\
\quad\left(y_{p}=\log _{10}[\text { 点滴前Ca値 }]\right.
\end{gathered}
$$

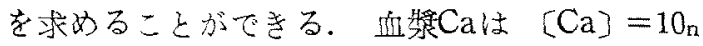

\begin{tabular}{|c|c|c|c|}
\hline 要 四 & 平力和 & 自由度 & 不霄分教 \\
\hline 值楾国憎 & $S_{R}$ & 1 & \\
\hline 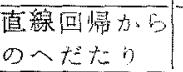 & $S_{D R}$ & $N-2$ & $V_{D R}=\frac{S_{D R}}{N-2}$ \\
\hline
\end{tabular}
$(10+\mathrm{T})^{\mathrm{b}}$ という実䍃式に促つて回復すること はなる。

\section{腎機能検查}

正常大 3 例，酒石酸ソーダ投与による近位尿細 管障害犬 3 例，昇乘注入による遠位尿細管障害犬 3例につき，近位尿細管機能としてPSP排泄試 験を，遠位层細管機能として濃縮試験, pitressin 試験を行なつた，PSP排泄試験は以下の如く 行なつた。すなわ水 $200 \mathrm{cc}$ 経口負荷後, 利尿 をつけるため $5 \%$ けブドウ糖と生理食塩水との等量 混合液を一定速度で点滴静注し，属量が活ぶ一定 した時にphenolsulfophthalein $1 \mathrm{cc} / 10 \mathrm{~kg}$ 静注, 15分， 30 分，1時間，2 時間にわたつてカテーテ ル尿を採取し，そのおのおのにつき $10 \% \mathrm{NaOH}$ 加え最も強く発色させた後, $1000 \mathrm{cc}$ に稀秎し，標 準液と比色した。

濃縮試験はFishberg氏法に準じ一夜絶食後, 翌朝 8 時, 9 時, 10 時の 3 回カテーテル瓜を蜉取 しおの扮のにつき比重測定を行なつた， pitre$\operatorname{ssin}$ 試験は $5 \%$ ブドウ糖と生理食塩水の等量混合 液を一定速度で点滴，原量がほぐ一定した後，15 分間隔で 2 時間にわたつて採尿，さらにpitressin 20 單位 (Park-Davis社製) を皮下注射し，以後15 分間隔で 2 時閒埰尿し，尿量，比重を測定した。

\section{III. 結 果}

正常大 6 例の期待回復持間（ETR）の平均値 々平均標準鿁差は $4.9 \pm 0.4$ であり，雨側蜸摘犬 6 例のETRの平均値注 $2.4 \pm 0.2$ で筒摘犬にお いて明らかに短縮を認め, 統計的に有意差がある。 $(P<0.001)$ (Table 1 a扩よびb).一方耐側尿管結 禁犬 4 例のET Rは4.5 00.2で正常犬との間に有

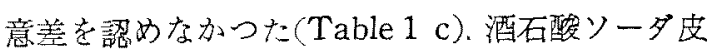
下注に上る近位沓細管障害大 5 例のETRの平均

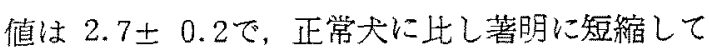
いるが $(\mathbf{P}<0.001)$, 他万舅录注入による遠位尿細

\begin{tabular}{|c|c|c|c|c|c|c|c|c|c|c|c|c|c|c|}
\hline \multirow{2}{*}{ DOE No. } & \multirow{2}{*}{$\begin{array}{c}\text { Initial } \\
\text { value }\end{array}$} & \multirow{2}{*}{$\begin{array}{l}\text { End of } \\
\text { inf. }\end{array}$} & 0.25 & 0.5 & 1 & 1.5 & 2 & 2.5 & 3 & \multirow{2}{*}{ Fo } & \multirow{2}{*}{$P$} & \multirow{2}{*}{ a } & \multirow{2}{*}{$b$} & \multirow{2}{*}{$E I R$} \\
\hline & & & & $\mathrm{Hx}$. & & d 0 & & & & & & & & \\
\hline
\end{tabular}
管障害犬 3 例のETR平均值は $5.8 \pm 1.0$ で，正

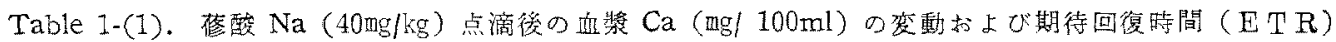

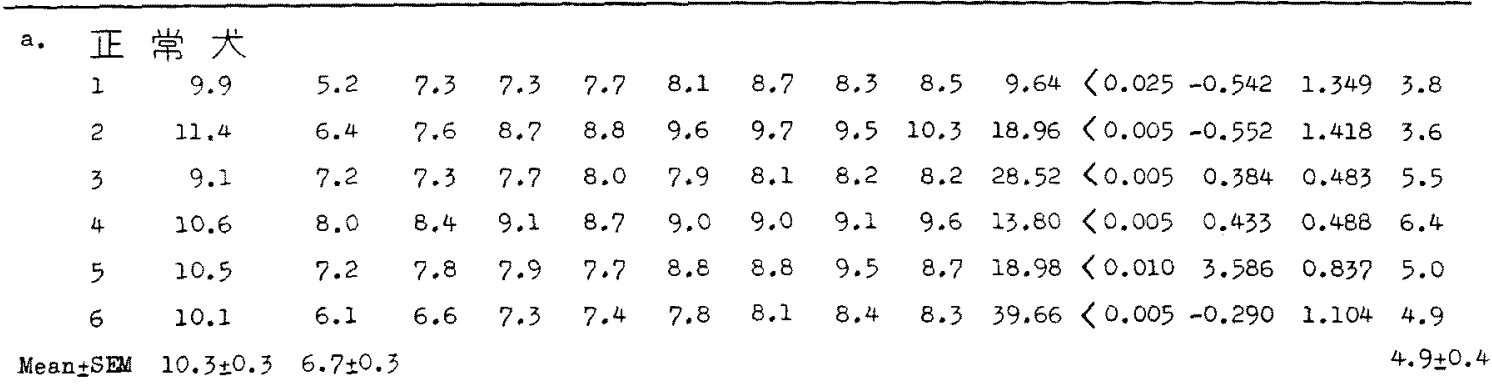


Table 1-(2)

\begin{tabular}{|c|c|c|c|c|c|c|c|c|c|c|c|c|c|c|c|}
\hline \multirow[t]{2}{*}{ DOE } & \multirow[t]{2}{*}{ No. } & \multirow{2}{*}{$\begin{array}{l}\text { Initial } \\
\text { value }\end{array}$} & \multirow{2}{*}{$\begin{array}{l}\text { End of } \\
\text { inf. }\end{array}$} & 0.25 & 0.5 & 1 & 1.5 & 2 & 2.5 & 3 & \multirow[b]{2}{*}{ Fo } & \multirow[b]{2}{*}{$F$} & \multirow[b]{2}{*}{$\bar{a}$} & \multirow[b]{2}{*}{$b$} & \multirow[b]{2}{*}{ ETR } \\
\hline & & & & & $\mathrm{Hr}$. & after & end of & infus & ion & & & & & & \\
\hline 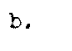 & \multicolumn{15}{|c|}{ 画側㹂楛犬 } \\
\hline & 1 & 9.0 & 6.4 & 6.6 & 6.5 & 7.6 & 7.7 & 8.0 & 8.5 & 9.0 & 139.31 & $<0.005$ & -0.510 & 1.314 & 3.0 \\
\hline & 2 & 11.4 & 7.5 & 8.8 & 9.7 & 10.8 & 11.2 & 11.0 & 10.9 & 11.0 & 11.35 & $<0.025$ & -0.267 & 1.204 & 2.6 \\
\hline & 3 & 9.3 & 5.5 & 7.1 & 8.2 & 8.2 & 9.0 & 9.4 & 10.3 & 9.9 & 22.52 & $<0.005$ & -1.080 & 1.899 & 2.0 \\
\hline & 4 & 11.0 & 7.3 & 8.3 & 8.7 & 20.6 & 10.6 & 10.6 & 10.7 & 10.9 & 17.91 & $<0.005$ & -0.469 & 1.379 & 2.5 \\
\hline & 5 & 7.9 & 6.2 & 7.2 & 7.6 & 7.1 & 7.6 & 7.4 & 8.1 & 8.2 & 11.09 & $<0.025$ & 0.927 & 0.737 & 2.3 \\
\hline & 6 & 11.6 & 8.3 & 9.8 & 10.6 & 12.3 & 11.9 & 12.1 & 12.0 & 12.1 & 10.07 & $<0.025$ & -0.179 & 1.161 & 2.8 \\
\hline
\end{tabular}

NeantSEM $10.0 \pm 0.6 \quad 6.9 \pm 0.4$

$2.4 \pm 0.2$

c. 画側层管結禁犬

$\begin{array}{rrrrrrrrrrrrrrr}1 & 12.3 & 8.3 & 9.4 & 9.7 & 10.2 & 10.1 & 10.3 & 10.6 & 11.0 & 22.19<0.005 & 0.150 & 0.804 & 4.8 \\ 2 & 8.7 & 7.5 & 7.5 & 7.9 & 8.0 & 8.2 & 8.1 & 8.2 & 8.5 & 35.99<0.005 & 0.456 & 0.424 & 3.9 \\ \dot{3} & 9.2 & 7.1 & 7.1 & 7.9 & 8.0 & 8.7 & 8.6 & 7.9 & 8.4 & 6.95<0.050 & 0.269 & 0.599 & 4.4 \\ 4 & 9.4 & 7.3 & 7.6 & 8.3 & 8.4 & 8.5 & 7.9 & 8.7 & 8.8 & 8.62<0.050 & 0.350 & 0.534 & 4.7\end{array}$

Mean + SEM $9.9 \pm 0.8 \quad 7.6 \pm 0.3$

$4.5 \pm 0.2$

Table 1-(3)

\begin{tabular}{|c|c|c|c|c|c|c|c|c|c|c|c|c|c|c|}
\hline \multirow{2}{*}{ Dog No. } & \multirow{2}{*}{$\begin{array}{l}\text { Initial } \\
\text { value }\end{array}$} & \multirow{2}{*}{$\begin{array}{l}\text { End of } \\
\text { inf. }\end{array}$} & 0.25 & 0.5 & 1. & 1.5 & 2 & 2.5 & 3 & \multirow[b]{2}{*}{ Fo } & \multirow[b]{2}{*}{$\mathrm{F}$} & \multirow[b]{2}{*}{$\mathrm{a}$} & \multirow[b]{2}{*}{$\mathrm{b}$} & \multirow[b]{2}{*}{ ETP } \\
\hline & & & & $\mathrm{Hr}$. & $r$ & of & fus & & & & & & & \\
\hline
\end{tabular}

d. 酒后酸ソーダ投与犬

$\begin{array}{llllllllllllll}1 & 10.5 & 8.9 & 9.2 & 9.9 & 10.0 & 9.2 & 10.4 & 10.7 & 10.7 & 13.45<0.025 & 0.334 & 0.627 & 2.5 \\ 2 & 10.1 & 7.8 & 8.9 & 9.0 & 9.1 & 9.6 & 9.5 & 9.4 & 9.9 & 12.99<0.025 & 0.298 & 0.629 & 3.3 \\ 3 & 9.3 & 6.9 & 8.1 & 8.1 & 8.1 & 8.4 & 8.8 & 8.9 & 9.2 & 21.69<0.01 & 0.570 & 0.818 & 3.0 \\ 4 & 9.2 & 8.6 & 8.8 & 8.7 & 8.7 & 9.1 & 9.6 & 9.2 & 9.0 & 5.99<0.05 & 0.667 & 0.271 & 2.5 \\ 5 & 9.1 & 7.4 & 7.6 & 7.9 & 8.9 & 9.0 & 8.8 & 8.9 & 9.5 & 27.17<0.005 & 2.237 & 0.860 & 2.3\end{array}$

Nean \pm SEM $9.6 \pm 0.3 \quad 7.9 \pm 0.4$

e. 昇录注入犬

\begin{tabular}{|c|c|c|c|c|c|c|c|c|c|c|c|c|}
\hline 13.2 & 9.7 & 10.9 & 10.7 & 10.9 & 11.1 & 11.1 & 11.6 & 11.9 & 19.30 & $<0.005$ & 0.457 & 0.554 \\
\hline 9.0 & 7.3 & 7.3 & 7.6 & 7.7 & 7.7 & 7.6 & 7.8 & 8.3 & 18.47 & 0.005 & 0.496 & 0.369 \\
\hline 10.9 & 5.0 & 6.8 & 8.3 & 8.3 & 8.5 & 8.8 & 8.5 & 8.9 & 7.09 & $<0.05$ & -0.698 & 1.508 \\
\hline
\end{tabular}

Hean \pm SEM $11.0 \pm 1.27 .3 \pm 1.0$

Table 10 洴

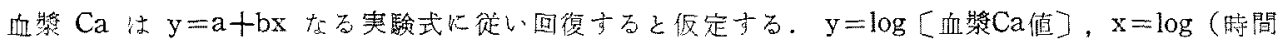

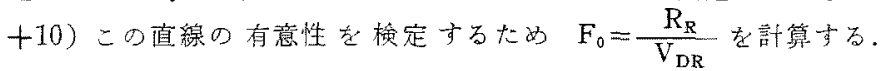

$\left(\mathrm{S}_{\mathrm{R}}=\frac{(\mathrm{Sxy})^{2}}{\mathrm{Sxx}}, \mathrm{S}_{\mathrm{DR}}=\mathrm{Syy}-\mathrm{S}_{\mathrm{R}}, \mathrm{V}_{\mathrm{DR}}=\frac{\mathrm{S}_{\mathrm{DR}}}{\mathrm{N}-2}, \mathrm{Sxx}, \mathrm{Syy}\right.$ 络各 $\mathrm{x}, \mathrm{y}$ の平力和t表わし $\mathrm{Sxy}$ は共 変動, Nはサンブル数を表方す）

$\mathrm{F}_{0}<\mathrm{F}_{\mathrm{N}-2}(0.05)$ の時にこの直線は有意となり，期待回復時間（ETR）は次式により計算される。 $\mathrm{ETR}=\operatorname{anti} \log \left(\frac{\mathrm{y}_{\mathrm{p}}-\mathrm{a}}{\mathrm{b}}\right)-10, \quad\left(\mathrm{y}_{\mathrm{p}}=\right.$ 血獎 Ca 点滴前值 $)$ 


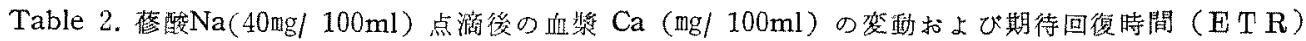

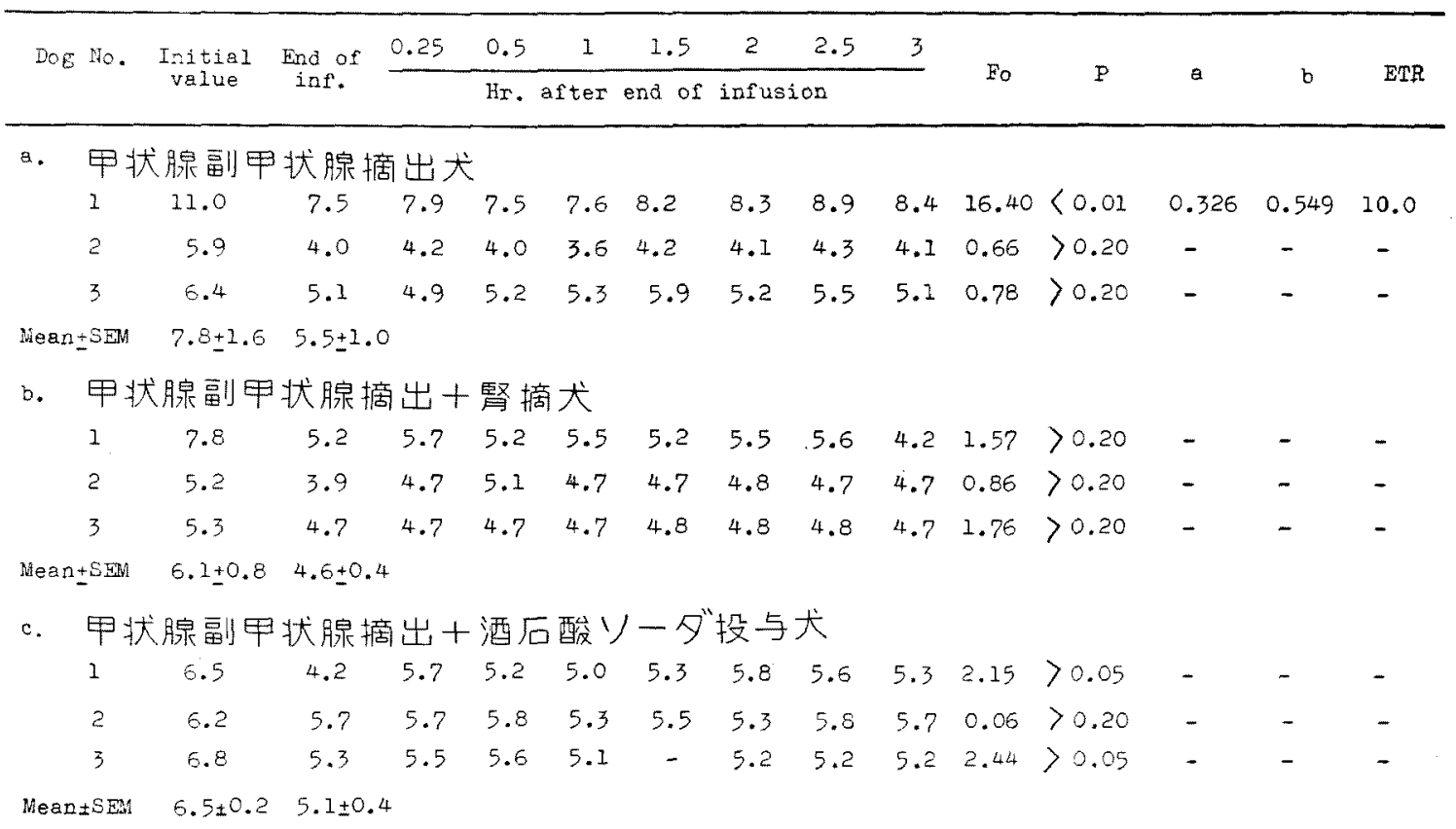

常犬との間に有意荎は認められなかつた（Table 1 e).

甲状腺副甲状腚摘出犬 3 例中 2 例 任血獎 $\mathrm{Ca}$ と 時間に10を加えた值の対数値間に直線の有意性が なく，ETRO計算は不能であり，直線の有意性 を示した 1 例のETRは10.0と著しく超長してい た (Table 2). 甲状腺副甲状腺摘出後，耐側腎摘 乃至は酒石酸ソーダ投与大掞のおの3例で柱，全 例において直線の有意性がみら扎ず，ETRの計 算は不能ですつた (Table 2).

腎機能椮榅の結果は正常大 3 例にお いてはPSP排泄值15分值肪平均21

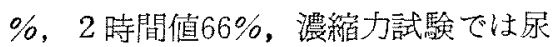
最亮比重 1050, pitressinに奶する反 応は良好であつた，泪石酸ソーダ投与 犬 3 例で江PSP排泄試験の子著明に

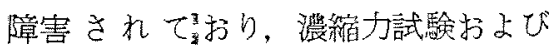
pitressin試験注正常範囲にあり，一方 昇采注入大で法PS P排泄試験はや

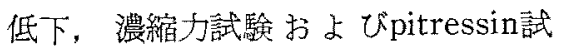
験は著明に低下していた(Table 3).

組織学的検索では酒石酸ソーダ投与 犬においては近位泉細管の硝子要性が

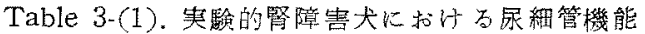

\begin{tabular}{|c|c|c|c|c|c|c|c|}
\hline & $\sqrt{2}$ & \multicolumn{2}{|c|}{ 正常茾 } & \multicolumn{2}{|c|}{ 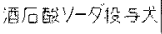 } & \multicolumn{2}{|c|}{ 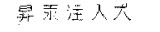 } \\
\hline \multirow{4}{*}{$\begin{array}{c}D S P \\
\text { ，排泄試独 }\end{array}$} & & 15>绐 & 2晆盟恼 & 159 偠 & 2時缄倓 & 15 斗偘 & 已昰留倍 \\
\hline & 1 & $19 \%$ & $68 \%$ & $8 \%$ & $27 \%$ & $12 \%$ & $50 \%$ \\
\hline & 2 & $23 \cdots$ & $62 \cdots$ & $10 \%$ & $34 "$ & 6 & $52 \%$ \\
\hline & 3 & $22 \% 1$ & $20 \%$ & $2 e^{\prime \prime}$ & $35 \%$ & $12 "$ & $50 \%$ \\
\hline \multirow{3}{*}{ 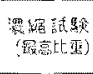 } & 1 & \multicolumn{2}{|c|}{1063} & \multicolumn{2}{|c|}{1038} & \multicolumn{2}{|c|}{1024} \\
\hline & 2 & \multicolumn{2}{|c|}{1032} & \multicolumn{2}{|c|}{1040} & \multicolumn{2}{|c|}{1024} \\
\hline & 3 & \multicolumn{2}{|c|}{1055} & \multicolumn{2}{|c|}{1045} & \multicolumn{2}{|c|}{1014} \\
\hline
\end{tabular}

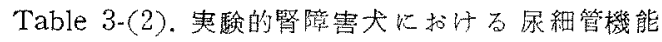
(pitressin 試䴋)

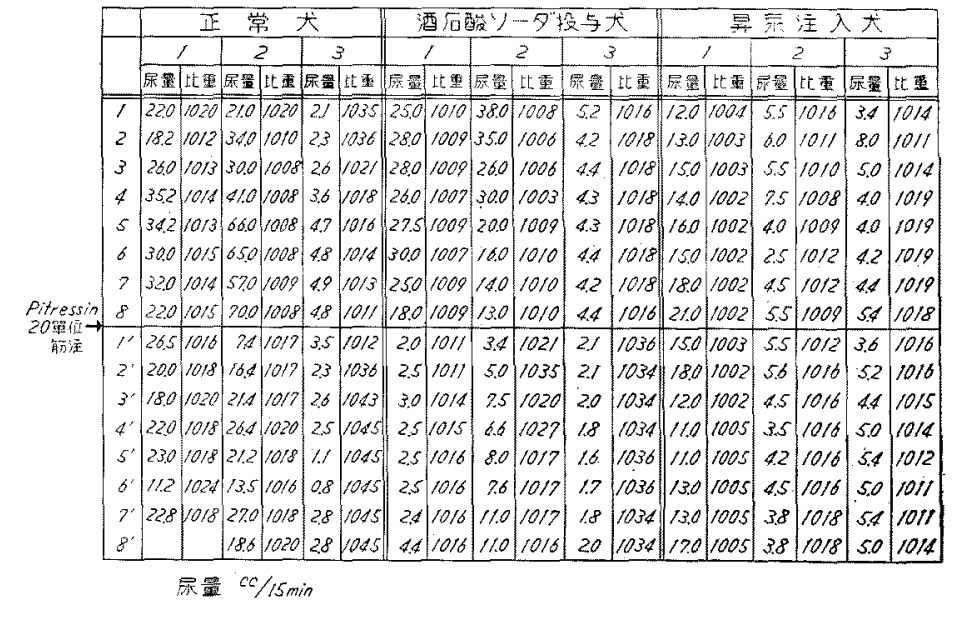




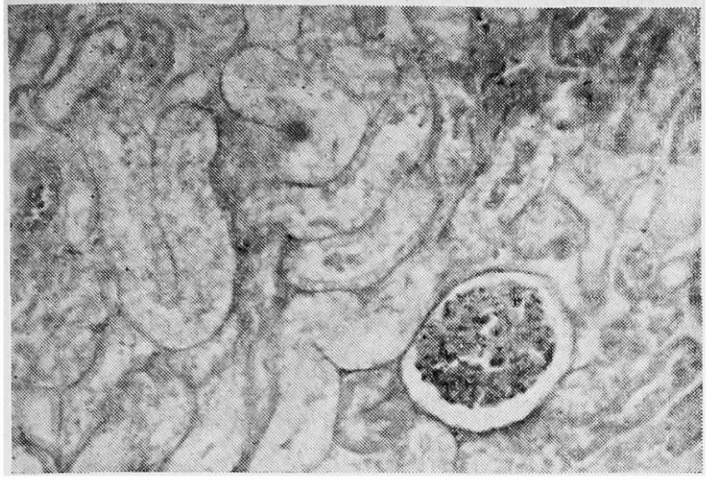

Fig. 1. 酒石酸ソーダ投与犬では近位尿細管の硝子 変性(図で左上)が著明に認められるが, 糸球体, 血管系および遠位尿細管には殆ど変化はない。

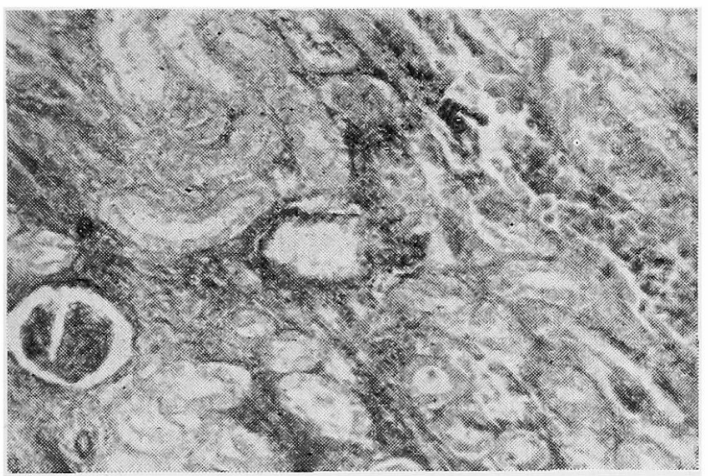

Fig. 2. 昇采注入犬では遠位尿細管の軽度腫脹, 輪 郭の不明瞭化, 管腔内出血（図で右下）が認めら れるが，近位尿細管，系球体，血管系の変化は 軽度である。

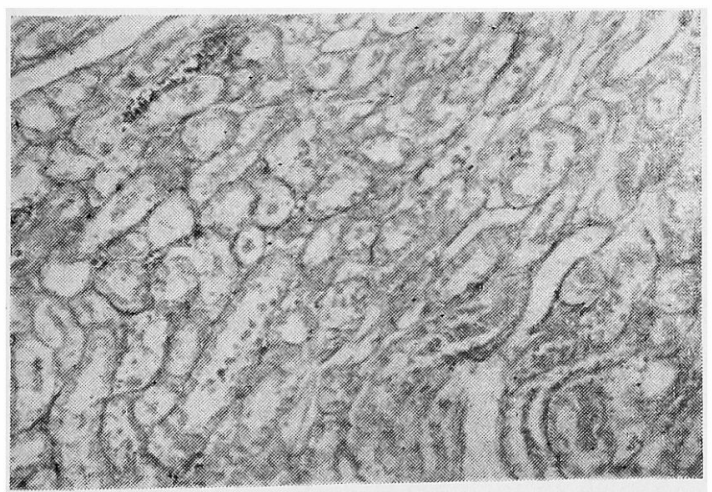

Fig. 3. 両側尿管結禁犬では近位，遠位尿細管の軽 度拡張のみが認められる。
Table 4. 実験的腎障害犬に拈ける血清 $\mathrm{Ca}, \mathrm{P}$ 値

\begin{tabular}{|c|c|c|c|}
\hline & $\begin{array}{c}\text { 垔物 } \\
\text { 数 } \\
\end{array}$ & $\begin{array}{c}\text { 血清 Ca } \\
(\mathrm{mg} / 100 \mathrm{~m} \text { 土SE }) \\
\end{array}$ & $\begin{array}{c}\text { 血清 } P \\
(\mathrm{mg} / 100 \mathrm{~m} \ell \pm S E)\end{array}$ \\
\hline 正常犬 & 6 & $10.3 \pm 0.3$ & $3.6 \pm 0.2$ \\
\hline $\begin{array}{l}\text { 蜸摘 犬 } \\
\text { 通捘 }\end{array}$ & 6 & $10.0 \pm 0.6$ & $3.7 \pm 0.1$ \\
\hline 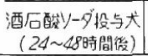 & 5 & $9.6 \pm 0.3$ & $4.2 \pm 0.2$ \\
\hline
\end{tabular}

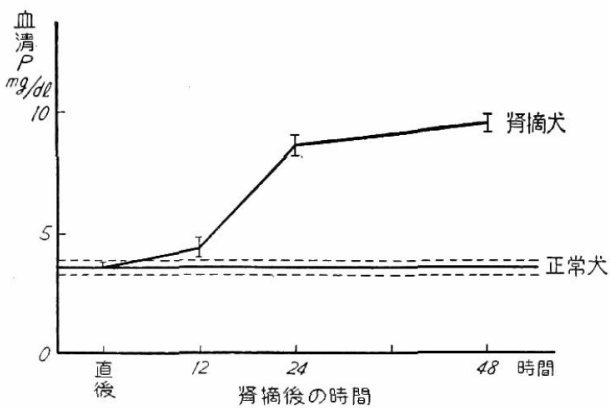

Fig.4.腎摘犬に打ける血清 $\mathrm{P}$ の時間的变動

著明に認められるが，糸球体，血管系および遠位 尿細管には殆ど変化がなかつた (Fig.1). 昇采注 入犬では,これに対し, 遠位尿細管細胞の軽度腫 脹, 輪郭の不明膫化，管腔内出血が認められ， 近位尿細管, 糸球体の变化は極く軽度であつた

(Fig. 2).

両側尿管結禁大では近位, 遠位尿細管の軽度拡 張のみが認められた (Fig. 3).

血漿Ca值の変動は腎摘犬, 酒石酸ソーダ投与 大，昇录注入犬，尿管結禁大のいずれにおいても 殆ど認められなかつた（Table 4, Fig. 4)。血 清 $\mathrm{P}$ は腎摘犬では上昇が認められたが，酒石酸ソ ーダ投与犬では正常範囲にあつた。

\section{IV. 考察}

副甲状腺の機能は 血清Caを一定に保つことに あるが，また一方その機能調節は血清中Ca イオ ンにより行なわれていると考えられている。しか し, その他の調節機構, 例えば血清 $\mathrm{P}$, 腦下垂体, 性腚, 副腎, 腎, 神経系の関与については, なお 不明の点が多い.内科臨床の面では, 副甲状腺と腎 とは最も密接な関係を有し, 慢性腎疾患の際の続 
発性副甲状㟫機能元進症は古くから注目されてお り，また生理学的にも副甲状腺ホルモンの作用部 位上して留名古く加方研究刘象となつている。ま ず副甲状腺ホルモンの留に対する作用としては， 尿中燐排泄增加方最も重要であり，その機序とし ては，近拉尿細管での燐再吸收抑制および遠位尿 細管加らの燐排泄促進の二つが考えられている。 かつては副甲状腺ホルモンのこの症中辚排洲增加 作用は，GFRの増大による間接作用と考えられ たこともあつたが，Rasmussenら7は彼らの精製 副甲状腙ホルモンを大の腎動脈に注入すると，注 射した側の督のみから燐排泄増加がみられ，その 際GFR，RPFは变化しないことを見出し，副 甲状腺ホルモンが直接掔に作用寸ることを確認し た。副甲状腺ホルモンの作用部位にかんしては， Nicholson8 は大だ昇承注入により撰択的に遠位层 細管を障害すると，副甲状腺ホルモンを投与して も燐排泄は起こらないのに対し，一方酒石酸ソ一 ダの腎動脈注入により近位尿細管障害を起こさせ た際には，副甲状腺ホルモンの燐排泄作用には変 化のみられない点から，副甲状腺ホルモンは遠位 尿細管に作用し，その燐分泌を促進するものと結 論した。しかし，Bartterら9は近位尿細管におけ る烧再吸收抑制説を主張し，未だ意見の一致を みるに至つていない，臨床的には慢性蟹疾患の際 の副甲状腺の变化が注目されており，Pappenhei-

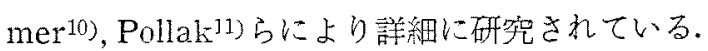
すなわちPappenheimerら10)は27例の腎疾患例に おいて，個体の副甲状腺重量（通常 4 個の重量） が正常の117mgに比し 177mgに増加し, 重症例で は244mgに達するものを認め，組織学的にも実質 細胞の増加, 脂肪, 結合組織の減少, 水椂透明細 胞の增加，妪酸球の減少を認めた。 Pollakら11)は 慢性婜矣患の約 $1 / 5$ に副甲状腺肥大を認めたと述ぺ ている、実験的にも慢性珡炎㭧者の血液，腎摘犬 の血液が，ウサギの血清Ca草上昇させることが報

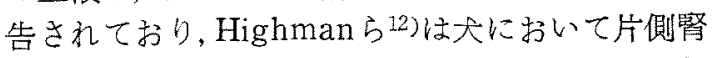
半摘後, 他側腎摘を行なうと, 副甲状腺肥大を起 こすと述へている. Talmage ら ${ }^{13)}$ は破骨細胞数 を副甲状腺機能の指標とし，腎摘シットでは破骨
維胞数が増加することから，腎摘により副甲状腺 機能克進を来たすと考えた. Lehrら $\left.{ }^{13}\right)$ はットに 腎摘，あるいはスルフォンアミト投与により筲障 害を惹起させると特異的な血管壊死を生ずるが， 予め副甲状腺摘出を行なうとこれが完全に防止で きることを報告しており，ある種の血管壊死の 発生に书と副甲状腺が重要な役割を演ずると考え た. Goldblattウサギでは特有な血管罣死の発生 坊，認女られるが，藤田ら15)は片側Goldblattウ サギにおいて血中副甲状腺ホルモン様物質の增加 を諗めている。

以上の如く腎と副甲状腺にかんする研究は多方 面加方行なわれているが，尿細管障害の際の副甲 状腺機能にかんしては極めて知見に乏しい現状で ある. 徒つて本研究においては副甲状腺機能の指 標として苳酸Na負荷試駰を用い, 㩲択的尿細管障 害犬における副甲状腺機能につき検討した。葆酸 $\mathrm{Na}$ 負荷に上る低Ca血症加らの血清Caの回復は, 副甲状腺摘出犬では正常大に比し著しく遅延し, StewartおよびBowen゙はこの方法が副甲状腺機 能表珼し得ると考元, Copp ら16) 苳酸Naの代 りにEDTAを用い同様の結果を報告している。 犬においては副甲状腺摘出後, 血清Ca は 5 時間 目に低下し始めるとされているが, Hastings ら 17)によると，血中副甲状腺ホルモンは 6 時間後に はなお残つており，24時閒後には消失するとい う. Coppら (16)は副甲状腺摘出直後に EDTAを 負街した犬では，低Ca血症からの回復は荤延は するが軽度に回復し，2週間前に副甲状腺を摘出 し血清Caが $6 \mathrm{mg} / 100 \mathrm{ml}$ に低下した大では， E DTA 点滴後の低Ca血症は的 6 時間で点滴前の レベルに回復すると述へている，本実験では副甲 状腺摘出後24時間から72時間に苳酸 $\mathrm{Na}$ 僓荷試験 を行なつたが, 全例とも血清Ca低下からの回復 は著しく遅延し， 1 例のみ 10.0 時間後に回復した のみで，他ではすべて回復が認められなかつた。 血清Caの回復に副甲状腚が関与していることは, 杀井らが示した如く, 副甲状腺摘出大に苳酸 $\mathrm{Na}$ 点 滴直後Eli-Lilly社の“Parathyroid Injection”を 1 回静注すると投与量に汪ぶ平行して血清Ca回 
復が促進されることからも裏村けられる。贅摘お よび酒石酸ソーダ投与による近位尿細管障害大 では葆酸Na負荷による低Ca血症からの回復が 促進してるり，副甲状腺機能兄進を示唆するが， この原因としては臂摘，酒石酸ソーダ投与によ る血行動態の装化，底中Ca排泔の变化なども 考元られる枋，予め副甲状腺摘出を行なうと低 Ca血症からの回復が全然みられない点から， 副甲状腺の存在功不可欠のもの之考えられる。 原管結禁大，昇承注入に上る遠位尿細管障害大 では，低Ca血症斿らの回復は正常大と变らず， 副甲状腺機能は正常々者えら礼る，尿細管障害部 位により副甲状璄機能にかっる盖のみられること

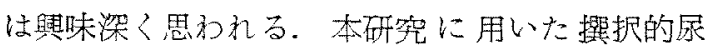
細管障害法はNicholsonらの方法3改変したも

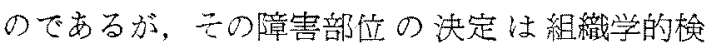
索ならびに機能検查を併用して行なつな。すな わち酒石酸ソーダ投与大では変性は主として近 位尿細管に限局し，PS P排泄試験は著明に障 害されているが，尿濃縮力，pitressin試験正常 であつた。一方，昇承注入大では，变性は主とし て遠位尿細管に限局しており，PＳＰ試験は軽度 障害, 濃縮力試験, pitressin試験㵔明に障害 されていた。すなわう障害部位の決定において組 織学的所見と機能娭査の結果とがかなり良く一致 したと考えられる。慢性腎疾患の際の副甲状腺機 能年進の機序としては, 糸球体㵙過值低下により 血清Pが上昇し，ての結果血清Caが低下，副甲状 腺が刺激されると考えられているが，腎摘大およ び酒石酸ソーダ投与による近位菂細管障害大に抒 いては血清Caはともに正常值を示し，血清Pは腎 摘犬では上昇するが，酒石酸ソーダ投与犬では㱠 ぼ不変であり,血清Ca，Pの歅動のみで,これらに おける副甲状腺機能九谁を境明するのは困奞と考 えられる、Elliott, Freemanら ${ }^{18}$ )はラットで腎摘 後, 血清Caの一時的上昇を認めたが，同時に血清 クエン酸も上昇することから，血清クエン酸の上 昇沙腎摘後の高Ca血症の原因々考えた.Dent ら ${ }^{19}$ は慢性腎疾患の際，血清 $\mathrm{P}$ 上昇の認められぬ例に
おいても血清Ca低下を来たす例のあること，ま たかっる例においてCaの腸管からの吸收障害が 認められることから，繁障害の際にはVitamin D に刘する感受性が低下するのではないかと考えて いる，著者 ${ }^{20}$ はin vitroでラッ卜腎切片方副甲状 腺ホルモン活性を著明に減弱させることを見出

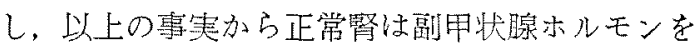
不活化するか，乃至はその作用を聇制する作用が あるが，掔障害の際にはこれらの作用が失われる ために副甲纸腺機能九進を来たすと考えている が，さらに墇細に朲討を続ける予定である。

\section{V. 結 論}

1）体重 $10 \mathrm{~kg}$ 前後の成犬に苳酸Na負荷試験を 行ない, 血洕Caの対数值と苳酸Na負荷直後加ら の時間に10を加えた値の齐数値間の直線性の有意 を検定した後, 最小二框法により実験式を求め期 待回復時間を計算した。

2) 甲状腺, 副甲状腺摘出犬で法期待回復時間 は延長しているが, 直線の有意性が認められなか つた.

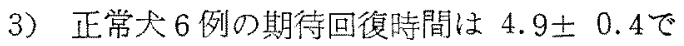
あつた。

4)腎摘犬および酒石酸ソーダ投与による近位 层細管障害大では全例において低Ca血症加らの 回復が速やかであり，期待回復時間はそれぞれ $2.4 \pm 0.2,2.7 \pm 0.2 て ゙$, 副甲状腺機能進が示 唆された。

5）尿管結禁犬，舁录注入による遠位尿細管障 害犬では低Ca血症からの回復は正常で，期待回 復時間沙のおの $4.5 \pm 0.2,5.8 \pm 1.0$ で, 副 甲状腺機能怔正常と考えられた。

6)予好甲状腺副甲状腺摘出後，腎摘万至は酒 石酸ソーダ投与を行ならと, 低Ca血症からの回復 は諗好的ず，直線の有意性がなかつた。

7) 酒石酸ソーダ投与大では変性は主として近 位尿細管に限局し，穖能的にはPSP排泄試験が 著明に障害され，层濃縮力， vasopressin試験は 正常であつた。一与辈承注大犬では変位は主とし て遠位原細管にみられ，PSP排泄試験怪軽度に 
障害され，家濃縮力，vasopressin試験は著明に 障害されていた。

8）筲摘犬においては血清Caは正常，血清 $\mathrm{P}$ は上昇, 酒石酸ソーダ投与大では血清 $\mathrm{Ca}, \mathrm{P}$ とも に正常範䀘であり，これらの際の副甲状腺機能九 進を血清 $\mathrm{Ca}, \mathrm{P}$ の変阷のみで説明するのは困難と 考えられた。

\section{文献}

1) McCallum, W.G.: Bull. Johns Hopk. Hosp., $16: 87,1905$. -2) Rasmussen, H.: J. biol. Chem., $235: 3442$, $1960 . \quad-3)$ Nicholson, T.F.: Canad. J. Biochem., $35: 641,1957$. -4) Stewart, G.S. and Bowen, H.F.: Endocrinology, 48: 568, 1951. -5) Morii, H., Fujita, T. and Okinaka, S.: Endocrinology, $72: 173,1962,-6)$ Munson, P.L., Iseri, O.A., Kenny, A.D., Cohn, V. H. and Sheps, M.C.: J. dent. Res., $34: 714$, 1955. -7) Pullman, T.N., Lavender, A.R., Aho, I. and Rasmussen, H.: Endocrinology, $67: 570$, 1960. -8) Nicholson, T.F.: Canad. J. Biochem.
$37: 113$, 1959. -9) Bartter, F.C.: The Parathyroids, Thomas, Springfield, Ill., p 473, 1961. -10) Pappenheimer, A.M., and Wilens, S.L.: Amer. J. Path., 11 : 73, 1935. -11) Pollak, V. E., Schneider, A.F., Freund, G. and Kark, R. M.: Arch. intern. Med., $103: 200,1959 .-12$ ) Highman, W.J. Jr. and Hamilton, B.: Arch. Path., $26: 1029$, 1938. -13) Talmage, R.V. and Toft, R.J.: The Parathyroids, Thomas, Springfield, Ill. p. 224, 1961. -14) Lehr, D.: Ann. N.Y. Acad. Sci., $72: 901,1959 .-15)$ Fujita, T., Morii, H. and Okinaka, S.: Endocrinology, 70: 711, 1962. -16) Copp, D.H., Moghadam, H., Mensen, E.D. and McPherson, C.D.: The Parathyroids, Thomas, Springfield, Ill., p. 203, 1961. - 17) Hastings, A.B, and Higgins, C.B.: Proc. Soc. exp. Biol. (N.Y.), $30: 48,1933$. -18) Elliott, J.R. and Freeman, S.: Endocrinology, $59: 181$, 1956. -19) Dent, C.E., Harper, C.M. and Philipot, G.R.: Quart. J. Med. $30: 1,1961$. -20）折茂㹂, 藤回拓男, 森井沿世, 并林博, 中 尾喜久：第37回日本内分泌学会総会にて器表. 